\title{
Sciendo
}

DOI 10.2478/afepuc-2020-0005

(C) Acta Facultatis Educationis Physicae Universitatis Comenianae 2020, 60(1): 55-74

\section{INTENSITY OF SOCCER PLAYERS`TRAINING LOAD IN SMALL-SIDED GAMES WITH DIFFERENT NUMBER OF PLAYERS}

\author{
Nikolas Nagy ${ }^{1}$, Miroslav Holienka ${ }^{1}$, Matej Babic ${ }^{1}$, Jakub Michálek ${ }^{2}$, Egon Kunzmann ${ }^{2}$ \\ ${ }^{1}$ Faculty of Physical Education and Sport, Comenius University in Bratislava, Slovakia \\ ${ }^{2}$ Faculty of Physical Education and Sport, Charles University, Czech Republic
}

\begin{abstract}
Summary. The main aim of this research was to compare differences in heart rate values (HR) of soccer players during small-sided games (SSGs) with different number of players. We assumed that the number of "neutral" player or players in small-sided games will significantly affect the intensity of SSGs and in this case the heart rate values of participating players. The experimental group consisted of older junior players from the FC DAC 1904 Dunajská Streda soccer club $(n=9)$. The heart rate values were evaluated on the basis of collected data, which we obtained using Polar sport testers and special software Polar Team ${ }^{2}$. In order to find out the statistical significance of the difference in heart rate was used the One-Way ANOVA and the Bonferroni post hoc test. The level of statistical significance we set at $5 \%$. We found out that with increasing number of "neutral" players' the intensity of small-sided games gradually decreased. During SSG1 (3 vs. 3), we recorded the highest achieved average heart rate

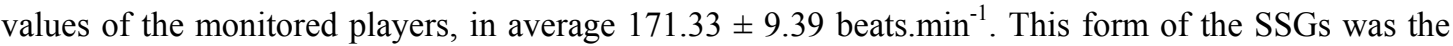
most intense, but not statistically significant. Our recommendation is to employ SSGs in the systematic training process with different number of players, because we can adequately prepare the players for the match load itself. Attention need to be paid for the playing position requirements.
\end{abstract}

Key words: soccer, training load intensity, heart rate, small-sided games, number of players.

\section{Introduction}

The continual development of soccer in the present is also influenced by the value of the systematic training process. By the increased game demands the level of the training process brings about important questions and tasks for coaching staff including the optimization and intensification of soccer players' training load intensity. In the purposefully designed training process of soccer players small-sided games have an inevitable role. Through small-sided games, it is possible to raise the level of technical 
preparedness, tactical independence, bio-energetic systems and emotional intelligence of players. During small-sided games players need to solve different complex game situations under the time and space deficiency and under active pressure of the opponent players. The conditions within small-sided games are closely related to the real match conditions.

The main aim of a systematic training process is to help increase the adaptation capacity

of player's organism to the load, with which players are closely confronted in the competitive match itself (Holienka 2004). The meaningful training process needs to focus on the creation of a specific adaptation change in the player's organism, which is induced by well-thought repeated adaptation stimuli (Holienka 2012). When work and rest ratio is proper, it contributes to the development, progressive increase, stabilization and observation of the training experience state, then we can note about the suitable training load (Kačáni 2005).

Holienka (2012) states that indicators of internal load, including the heart rate values (HR), make it possible to determine the usefulness and effectiveness of training load. Modern measuring devices of heart rate can record HR values with high accuracy and reliability. These devices provide exact feedback on actual reactions of the internal state of players' organism to the training load. Nowadays HR is a widely accepted and frequently used physiological indicator of the players' physical activity in the training process (Holienka 2016). During last couple of years monitoring the HR became a necessary part of the training load research in collective sports and many authors dealt with this issue in their research works (Aktas et al. 2014; Halouani et al. 2014a, 2014b; Randers et al. 2014; Gonzáles-Rodenas et al. 2015; Köklü et al. 2015; Torres-Ronda et al. 2015; Asci 2016; Campos-Vázquez et al. 2016; Clemente \& Nikolaidis 2016; Giovannelli 2016; Holienka 2016; Owen 2016; Sannicandro et al. 2016; Brandes et al. 2017; Clemente et al. 2017;González-Villora et al. 2017; Halouani et al. 2017; Proietti et al. 2017;Rojas-Valverde et al. 2017; Sannicandro \& Cofano 2017a, 2017b; Sánchez-Sánchez et al. 2017; Babic \& Holienka 2018; Babic et al. 2018; Giménez et al. 2018; Lacome et al. 2018; Malone et al. 2018; Nagy \& Holienka 2018; Peráček et al. 2018a, 2018b; Nagy \& Babic 2019; Nagy et al. 2019; Obetko et al. 2019; Nagy et al. 2020). Sport testers give us immediate feedback on the reaction of player's organism to the load (Benson a Connolly 2012). Monitoring of HR values is also used in youth soccer to gain valuable information and understand the physiological parameters of training units and match load (Owen 2016). 
Holienka (1998) stated that the principle - all with the ball - which currently is strongly required in training activities of soccer players, fulfils the game training (GT). The dominant position in it have different forms of SSGs, which include a lot of game situations that are similar to the competitive game situations occurring in the match. Training activity of players in collective sports games, like in soccer should take into consideration the specifics technical, tactical, physiological and psychological elements of individual game performance (Christopher et al. 2016; Zapletalová et al. 2017).

Therefore, the SSGs have become an inevitable part of the training units when increasing the level of game preparedness and fitness capacity of players. By applying the principle of "adequate coverage theory", we try to simulate in the training process through small-sided games such game conditions, which are similar to competitive match conditions and prepare players game-ready.

Small-sided games with different number of "neutral" players aim to improve the individual's game activities and game combinations in the development of youth soccer players. SSGs are widely used also in daily practice in the training units of the older and younger age categories. During SSGs players gain valuable experience in solving unique game situations, which constantly occur during the match. When solving various game situations during SSGs, the participating players are able to improve their skill potential, tactical variability, coordination - condition capabilities and they can increase their mental endurance level as well. Soccer coaches are able to influence the intensity of the training load during small-sided games if they adequately change the variables, which affect the intensity of SSGs. Among these variables we can mention for example: the number of players, playing field dimensions, coaching, game rules, content focus of the game, goal size, number of goals, presence of goalkeepers, work and rest ratio (Aktas et al. 2014; Randers et al. 2014; Young \& Rogers 2014; Köklü et al. 2015; Los Arcos et al. 2015; Torres-Ronda et al. 2015; Asci 2016; Holienka 2016; Christopher et al. 2016; Sannicandro et al. 2016; Brandes et al. 2017; Clemente et al. 2017; Eniseler et al. 2017; González-Villora et al. 2017; Halouani et al. 2017; López-Fernandéz et al. 2017; Praça et al. 2017; Rojas-Valverde et al. 2017; Sannicandro \& Cofano 2017a, 2017b; Giménez et al. 2018; Lacome et al. 2018; Mikulič et al. 2018; Nagy \& Holienka 2018; Sarmento et al. 2018, Sgro et al. 2018; Nagy \& Babic 2019; Nagy et al. 2019; Nagy et al. 2020).

Knowing that different number of players could affect the physiological responses and, therefore, the potential beneficial effect for individual and team performance improvement, it has to be noted how "neutral" players affect the intensity of SSGs. 
Thus, the main aim of the current study was to compare the effects of 4 forms of SSGs with different number of additional players (1, 2 or 3 floaters). These 4 forms of SSGs are indeed very popular and much used by soccer coaches during training sessions. The findings could potentially provide valuable, reliable and useful information to soccer coaches for the design different forms of SSGs as part of their training process.

\section{Methods}

In our research we monitored the internal response of players' organism expressed by the heart rate (HR) values in different forms of small-sided games (SSGs). The research consisted of monitoring of individually selected physiological load indicators during the training process. In our case, these were the HR values of young soccer players through SSGs with different number of "neutral" players. The dependent variable was the internal response of players' organism, expressed by the values of HR, and the independent variable was the number of "floaters" during the SSGs.

The research group consisted of players $(n=9)$ of the soccer club FC DAC 1904 Dunajská Streda (aged 17.8 \pm 0.7 years, body mass $68.5 \pm 6.1 \mathrm{~kg}$, body height $176.6 \pm 5.5$ $\mathrm{cm}, \mathrm{VO}_{2 \max } 61.06 \pm 3.24 \mathrm{ml} \cdot \mathrm{min}^{-1} \cdot \mathrm{kg}^{-1}$, maximum heart rate $\left(\mathrm{HR}_{\max }\right) 199.8 \pm 7.6$ beats. $\left.\mathrm{min}^{-1}\right)$. The monitored players were participants at the highest competition of this age category (U19) in Slovak Republic.

The main method used to obtain the research data was the measurement of heart rate values. The maximal heart rate $\left(\mathrm{HR}_{\max }\right)$ values were obtained by using the Hipp's field test (2007). The measurement of $\mathrm{HR}_{\max }$ were realized on artificial grass pitch in the MOL Football Academy in Dunajská Streda. After determination of the $\left(\mathrm{HR}_{\max }\right.$ values, we created 5 intensity load zones according to the level of difficulty, which were defined by the percentages of the $\mathrm{HR}_{\max }$ values.

\section{Table 1}

Intensity load zones according to the heart rate values (Moravec et al. 2007)

\begin{tabular}{|c|c|c|}
\hline Zone & \% HR $_{\max }$ & Character \\
\hline Zone 1 & $50-59$ & Very low intensity \\
\hline Zone 2 & $60-69$ & Low intensity \\
\hline Zone 3 & $70-79$ & Medium intensity \\
\hline Zone 4 & $80-89$ & Submaximal intensity \\
\hline Zone 5 & $90-100$ & Maximal intensity \\
\hline
\end{tabular}


To measure the HR level we used the sports test device POLAR TEAM. The calculation of the percentage and time spent of HR values in different zones of load intensity and determination of various $\mathrm{HR}$ value, $\%$ of $\mathrm{HR}_{\max }$ and time spent above the anaerobic threshold (ANT) was represented by using special software Polar Team.

Players were divided into two teams (3 vs. 3) according to their performance-related level. The players remained in the selected team during all four forms of the SSG. Goalkeepers did not have the sports testers on themselves, since we did not monitor the level of their HR values. The playing field with the size of $450 \mathrm{~m}^{2}$, (width $=18 \mathrm{~m}$, length $=25 \mathrm{~m}$ ) was marked out with cones and the portable goal had a standard size. There was a minimum of coaches' interaction during SSGs with verbal instructions but players could verbally encourage each other with the aim to maintain the intensity level of the SSG.

During the SSGs the minimal, average and maximal values of HR were recorded, abidance of players in individual intensity load zones and time spent above the ANT. We determined the HR values in four SSG variants, in which the size of the playing field, the main focus and the ratio of load interval to rest interval were the same. The load interval lasted 2 minutes, the rest interval was 2 minutes too (the ratio of LI to RI was 1:1). We intentionally change the number of "neutral" players.

\section{$\underline{S S G 1}$}

Players played the SSG 3 against 3 in a defined area with an unlimited number of ball contacts. The conditions in the SSG1 were same for both teams. The main aim of SSG1 was to create goal opportunities and finished the offensive phase of the game by shooting on the goal.

$\underline{S S G} 2$

Players played the SSG 3 vs. 3 and with 1 "neutral" player in a defined area with an unlimited number of ball touches. The conditions during the SSG1 were same for both teams. The "floater" was with the team in possession. The main aim of SSG2 was to create goal chances and finish the offensive phase of the game by shooting on the goal.

\section{$\underline{S S G 3}$}

Players played the SSG 3 vs. 3 in a defined area with an unrestricted number of ball contacts. Next to the side-lines were 2 more "neutral" players, who tried to help the players in possession. The conditions during the SSG3 were the same for both teams.

\section{$\underline{\text { SSG } 4}$}

Players played the SSG 3 vs. 3 and with 1 neutral player in a defined area with an unrestricted number of ball touches. Next to the side-lines were 2 more "neutral" players, who 
tried to help the players in possession. The "floater" was with the team in possession. The conditions during the SSG4 were same for both teams. The main aim of SSG4 was adequate situation solving (6 vs. 3 ) and goal chances creation with finishing the offensive phase of the game by shooting on the opponent's team goal.

Table 2

Different forms of small-sided games

\begin{tabular}{|c|c|c|c|c|c|c|c|c|c|c|}
\hline \multirow{2}{*}{ SSG } & Players & GK's & \multicolumn{2}{|c|}{ Field dimensions } & $\begin{array}{c}\text { Size of } \\
\text { field }\end{array}$ & \multicolumn{5}{|c|}{ Dosing of load } \\
\cline { 2 - 11 } & $(\mathrm{n}=9)$ & $(\mathrm{n}=2)$ & $\begin{array}{c}\text { width } \\
{[\mathrm{m}]}\end{array}$ & $\begin{array}{c}\text { length } \\
{[\mathrm{m}]}\end{array}$ & $\begin{array}{c}\text { RI } \\
{\left[\mathrm{m}^{2}\right]}\end{array}$ & $\begin{array}{c}\text { LI } \\
{[\mathrm{min} .]}\end{array}$ & $\begin{array}{c}\text { RI } \\
{[\mathrm{min} .]}\end{array}$ & NR & NS & $\begin{array}{c}\text { Load } \\
{[\mathrm{min} .]}\end{array}$ \\
\hline SSG1 & $3 / 3$ & $1 / 1$ & 18 & 25 & 450 & 2 & 2 & 4 & 1 & 8 \\
\hline SSG2 & $3 / 3+1$ & $1 / 1$ & 20 & 27 & 540 & 2 & 2 & 4 & 1 & 8 \\
\hline SSG3 & $3 / 3+2$ & $1 / 1$ & 18 & 25 & 450 & 2 & 2 & 4 & 1 & 8 \\
\hline SSG4 & $3 / 3+3$ & $1 / 1$ & 20 & 27 & 540 & 2 & 2 & 4 & 1 & 8 \\
\hline
\end{tabular}

To determine the statistical significance of the HR values the One-Way ANOVA method and Bonferroni post hoc test were used. The level of statistical significance was set at $5 \%$ level. The results were interpreted, compared and we tried to find connections between them. On the basis of these data, we have formulated conclusions and recommendations for didactic theory and training practice.

\section{Results}

The internal load of the soccer players' organism to the load during the SSG1

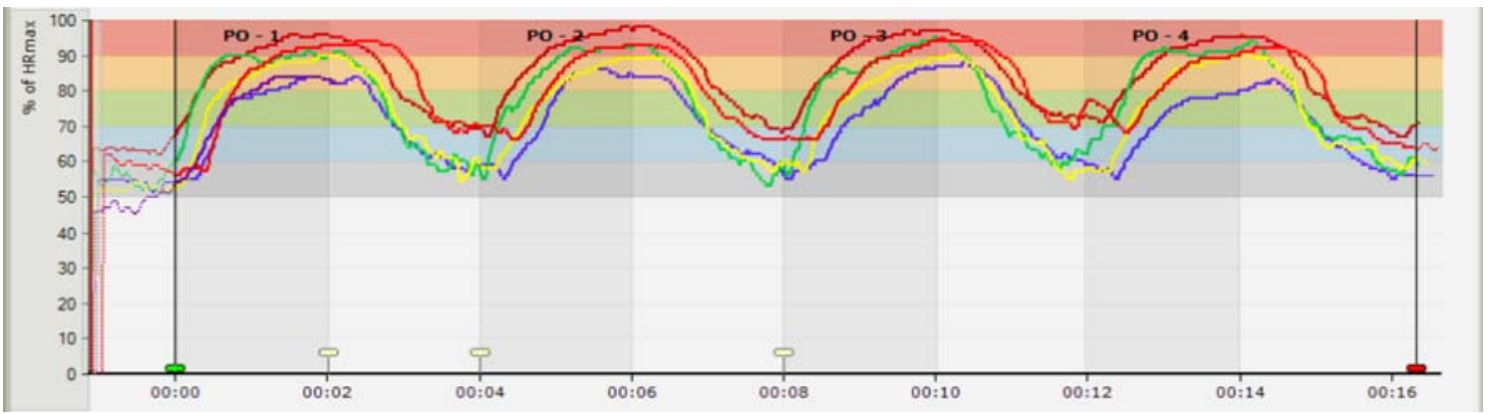

Figure 1

Physiological curves of the monitored soccer players in SSG1

In the above stated Figure 1 are depicted physiological curves of the six monitored soccer players during the SSG1. On this physiological curve, we can see a graphic illustration of the internal response of the soccer players' organism to the load in SSG1 when the work and rest ratio was on the same level $(1: 1)$. 
The internal load of the soccer players' organism to the load during the SSG2

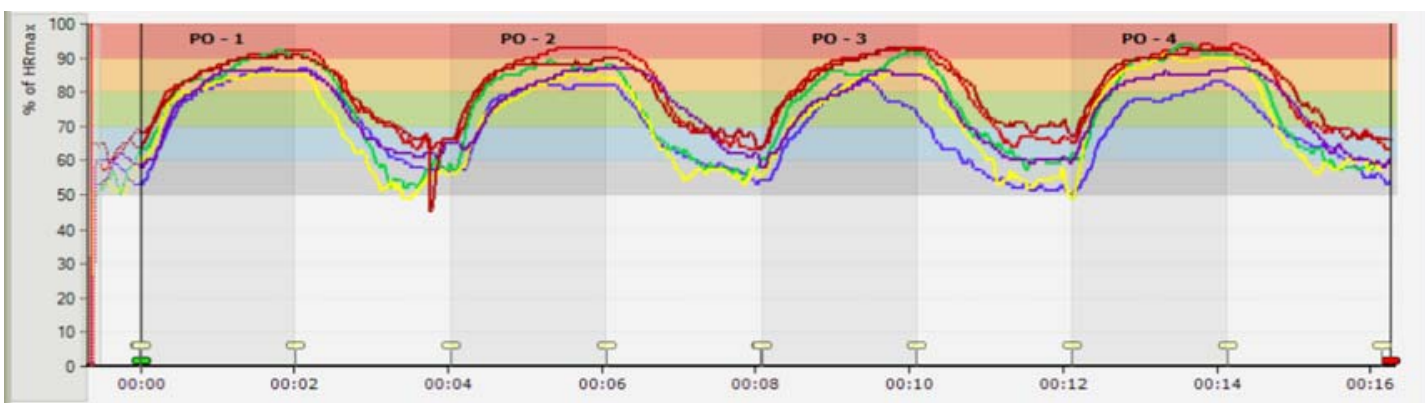

Figure 2

Physiological curves of the monitored soccer players in SSG2

In the above stated Figure 2 are represented physiological curves of the monitored soccer players during the SSG2. On this physiological curve, we can see a graphic illustration of the internal response of the soccer players' organism to the load in SSG2 with four different vertices representing four repetitions with the same work and rest intervals.

The internal load of the soccer players' organism to the load during the SSG3

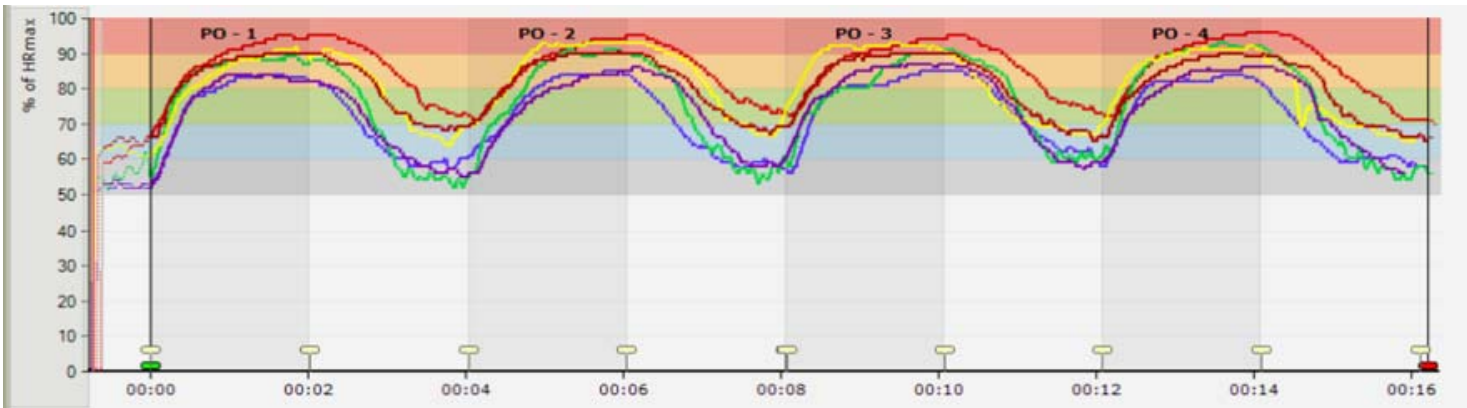

Figure 3

Physiological curves of the monitored soccer players in SSG3

In the above stated Figure 3 physiological curves of the monitored soccer players are represented, which refer to the equality of the work and rest intervals which lasted 2 minutes in four repetitions during the entire SSG3.

The internal load of the soccer players' organism to the load during the SSG4

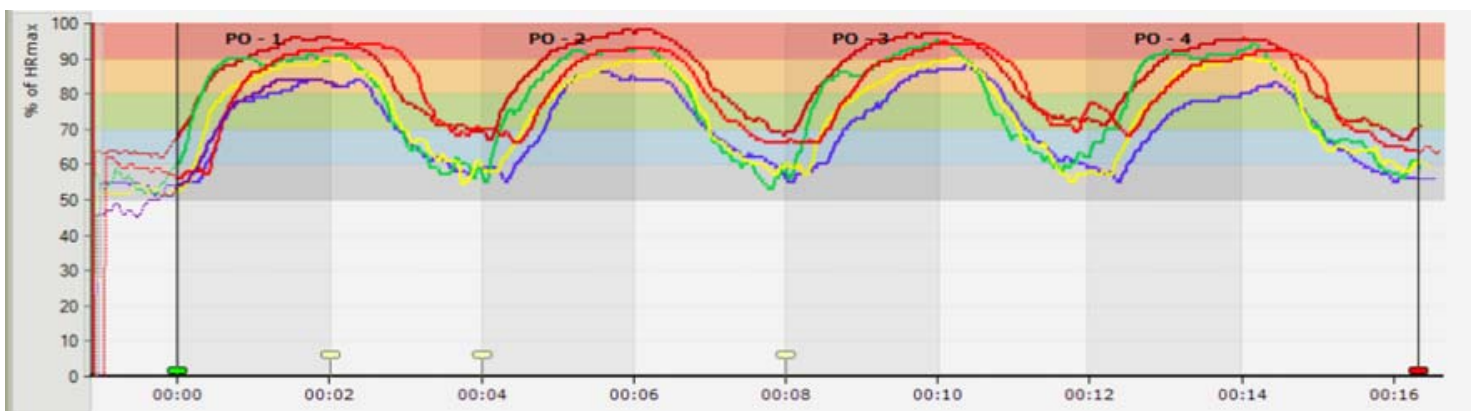

Figure 4

Physiological curves of the monitored soccer players in SSG4 
In the above stated Figure 4 the internal reactions of the soccer players' organism to the load during the entire SSG4 is represented.

The observed soccer players spent during the different forms of SSGs in advance selected intensity load zones different length of time. In table 3 you can see the average time values

and the percentage representation of players' remaining in different training load intensity zones.

Table 3

Remaining of players in different training load intensity zones

\begin{tabular}{|c|c|c|c|c|c|c|c|c|c|c|}
\hline $\begin{array}{l}\text { Load } \\
\text { zones }\end{array}$ & \multicolumn{2}{|c|}{$50-59 \% \mathrm{HR}_{\max }$} & \multicolumn{2}{|c|}{$60-69 \% H R_{\max }$} & \multicolumn{2}{|c|}{$70-79 \% \mathrm{HR}_{\max }$} & \multicolumn{2}{|c|}{$80-89 \% H_{\max }$} & \multicolumn{2}{|c|}{$90-100 \% H_{\text {max }}$} \\
\hline Intensity & \multicolumn{2}{|c|}{ Very low } & \multicolumn{2}{|c|}{ Low } & \multicolumn{2}{|c|}{ Medium } & \multicolumn{2}{|c|}{ Submaximal } & \multicolumn{2}{|c|}{ Maximal } \\
\hline SSG & [min.] & {$[\%]$} & [min.] & {$[\%]$} & [min.] & {$[\%]$} & [min.] & {$[\%]$} & [min.] & {$[\%]$} \\
\hline SSG1 & 0.4 & 0.31 & 1.39 & 9.01 & 4.15 & 26.03 & 4.06 & 25.41 & 6.16 & 38.86 \\
\hline SSG2 & 0.6 & 0.63 & 2.12 & 12.51 & 4.04 & 25.11 & 3.53 & 24.51 & 6.06 & 37.73 \\
\hline SSG3 & 0.7 & 0.66 & 3.31 & 21.78 & 3.23 & 21.05 & 4.25 & 27.41 & 4.41 & 29.48 \\
\hline SSG4 & 1.03 & 6.28 & 2.51 & 17.33 & 3.24 & 20.87 & 4.14 & 26.11 & 4.51 & 29.75 \\
\hline
\end{tabular}

The highest intensity of the training load was recorded during the SSG1, when the SSG was played 3 vs. 3 without any "neutral" player. Monitored soccer players remained through the SSG1 the longest time duration in the load zone of maximal intensity (90-100\% $\left.\mathrm{HR}_{\max }\right)$

on average 6.16 minutes (38.86\%) of SSG1 duration. We noted down least time duration in the load zone of very low intensity $\left(50-59 \% \mathrm{HR}_{\max }\right)$. In this zone remained the players 40 seconds $(0.31 \%)$. The lowest intensity was monitored during SSG4, when 3 additional "neutral" players tried to help solving game situations in the offensive phase of the game. On average players spent the most time space of the SSG4 duration in the load zone of very low and low intensity. Between SSG1 and SSG2 the internal reaction of players' organism was on the same rate. We cannot find any significant differences between SSG3 and SSG4 too. 


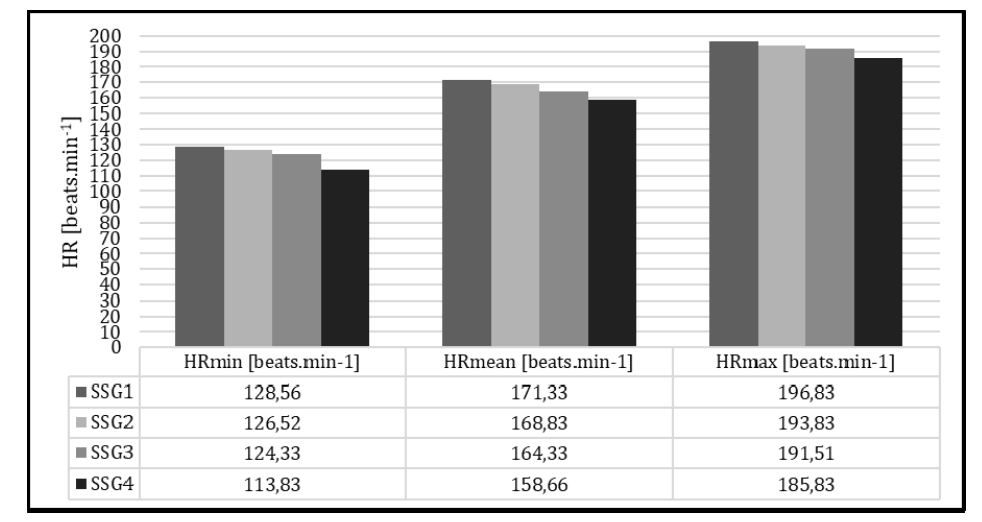

Figure 5

$H R$ values in $S S G S$

The internal load of monitored soccer player's organism to the training load during SSGs with different number of "neutral" players was observed by recorded the HR values. The highest average value of minimum $\mathrm{HR}\left(\mathrm{HR}_{\mathrm{min}}\right)$ was achieved by the observed soccer players during SSG1 ( 3 vs. 3), $128.56 \pm 11.48$ beats. $\mathrm{min}^{-1}$. The lowest values were monitored in the SSG4 (3 vs. $3+3$ "neutral" players), $113.83 \pm 9.31$ beats. $\mathrm{min}^{-1}$.

The average $\mathrm{HR}$ value $\left(\mathrm{HR}_{\text {mean }}\right)$ of the observed soccer players was the lowest in the SSG4 $158.66 \pm 8.09$ beats. $\min ^{-1}$ and the highest during SSG1 $171.33 \pm 9.39$ beats. $\mathrm{min}^{-1}$. The recorded average value of maximal $\mathrm{HR}\left(\mathrm{HR}_{\max }\right)$ was the lowest in the SSG4 $185.83 \pm 9.06$ beats. $\mathrm{min}^{-1}$ and the highest through SSG1 $196.83 \pm 6.96$ beats. $\mathrm{min}^{-1}$.

In the SSGs with low number of players (3 vs. 3), the training load is often higher than the competitive match load itself. The recorded ascertained values of $\mathrm{HR}_{\max }$ show that players performed the training activity at a high level. There are no significant differences between the ascertained percentage values from $\mathrm{HR}_{\max }$. We can see that the highest value we recorded during SSG1 (96.66 \%) and the lowest in the SSG4 (92.66\%).

Table 4

\begin{tabular}{|c|c|c|c|c|}
\hline \multirow{2}{*}{ SSG } & \multicolumn{2}{|c|}{ HR $_{\max }$} & \multicolumn{2}{c|}{ \% HR $_{\max }$} \\
\cline { 2 - 5 } & {$[$ beats.min } & \\
\hline \multirow{2}{*}{ SSG1 } & SD & {$[\%]$} & SD \\
\hline SSG2 & 196.83 & 6.96 & 96.66 & 2.51 \\
\hline SSG3 & 193.83 & 6.82 & 95.51 & 2.58 \\
\hline SSG4 & 191.51 & 8.68 & 94.33 & 3.72 \\
\hline
\end{tabular}

In modern soccer the match load is around the level of the anaerobic threshold (ANT). During the training units in the SSG with different number of players the training load was at a higher level. In this case the time spent above the ANT represents higher values.

\section{Table 5}

Time spent above the ANT 


\begin{tabular}{|c|c|c|}
\hline \multirow{2}{*}{ SSG } & \multicolumn{2}{|c|}{ Time spent above the ANT } \\
\cline { 2 - 3 } & {$[\mathrm{min}]$} & {$[\%]$} \\
\hline SSG1 & 7.06 & 43.96 \\
\hline SSG2 & 7.01 & 43.61 \\
\hline SSG3 & 5.36 & 34.83 \\
\hline SSG4 & 5.32 & 34.06 \\
\hline
\end{tabular}

Monitored soccer players spent the most time above the ANT during SSG3, it was up to 7.06 minutes $(43.96 \%)$ of SSG1 duration and the least time duration was registered in the SSG4 5.32 minutes (34.06 \%) of the SSG's total time.

On the basis of the One-Way ANOVA results, we can't found out statistically significant differences in average heart rate values after completing the SSGs with different number of "neutral" players $(\mathrm{F}=2.8465, \mathrm{p}=0.0635)$. The statistical significance between the SSG1 and SSG2 was not proved $\left(\mathrm{t}=0.5361\right.$, N. S.). The difference between the $\mathrm{HR}_{\text {mean }}$ was 2.5 beats. $\min ^{-1}$. It was probably caused by the fact that the one extra "neutral" player did not significantly influence the physical and game activity of other players, and therefore, the mean values of HR were not significantly different. After comparing mean HR values of SSG1 and SSG3 were not found any statistically significant difference of $\operatorname{HR}_{\text {mean }}(t=1.5011$, N. S.). During the SSG1 HR mean was171.33 \pm 9.39 beats. min $^{-1}$, during the SSG3 we recorded $\mathrm{HR}_{\text {mean }}$ values of 7.00 beats. $\mathrm{min}^{-1}$ more, $164.33 \pm 8.45$ beats. $\mathrm{min}^{-1}$. Statistically significant differences in the $\mathrm{HR}_{\text {mean }}$ values between the SSG1 and SSG4 were not proved $(\mathrm{t}=2.7162, \mathrm{~N}$. $\mathrm{S})$. The difference between the $\mathrm{HR}_{\mathrm{avg}}$ values was 12.67 beats. $\mathrm{min}^{-1}$. Three extra neutral "players" during SSG4 did not significantly affect the internal response of the other players' organism to the training load during the SSGs. Between the SSG2 and SSG3 no statistically significant lower $\mathrm{HR}_{\text {mean }}$ values $\left(\mathrm{t}=0.9650\right.$, N. S.) were found. In the SSG2 the $\mathrm{HR}_{\text {mean }}$ values were $168.83 \pm 5.98$ beats.min ${ }^{-1}$, in the SSG3 $\mathrm{HR}_{\text {mean }}$ values of 4.50 beats. $\min ^{-1}$ less, $164.33 \pm 8.45$ beats. $\mathrm{min}^{-1}$ were recorded. The comparison SSG2 with SSG4 statistically significant differences in the $\mathrm{HR}_{\text {mean }}$ values were not showed $\left(\mathrm{t}=2.1801, \mathrm{~N}\right.$. S). The difference between the $\mathrm{HR}_{\text {mean }}$ values was 10.17 beats. $\min ^{-1}$. Finally, the statistical significance between the SSG3 and SSG4 was not proved $(\mathrm{t}=0.2151$, N. S. $)$.

\section{Discussion}


Heart rate is a generally accepted and often used physiological indicator of the players' physical activity during the training sessions (Holienka \& Cihová 2016). When talking about the results obtained from the sports testers, we have to respect the general fact that the HR values showing the reaction of the soccer players' organism to the training load during different forms of SSGs are only indirect indicators. We can state that the SSGs in a well-thought training process enables the soccer players to constantly improve and stabilize the technical and tactical side of game situation solving, to increase the rate of creative thinking and their game actions on the soccer pitch. The variable conditions during different forms of SSGs ensure the realization of various series of individual's game activities and game combinations, which have a positive effect on space-time orientation, physical activity and players' emotions as well. The contradictory observance of opponent forces the players to quickly change the two main phases of the game, what means that, he can swiftly switch from defensive to offensive game phase and vice-versa and became a universal player. Sometimes soccer players must deal with unequal game situations, solve it with different number of players against different number of opponents. SSGs can prepare players adequately for this situation. The SSGs are a complex form of players' gaming development, owing to their high level of specificity it is possible to ensure a smooth development of their game performance efficiency (Babic 2016). The author claims that the SSG can be described as a complex element in the player's specific potential development.

Katis \& Kellis (2009) suggesting that the number of soccer players should be carefully considered by coaches in their organization. The authors suggested that SSG with low number of players can deliver a more effective technical training stimulus, since the number of different game situations increases with the decrease of players' number. During our forms of SSGs

the presence of "floaters" enhanced the success of game situation solving.

During training sessions it is common for soccer coaches to select SSG variations that involve a team playing with numerical advantage against another group of players with a numerical disadvantage (e.g., 4 against 3). It is also common to use SSG forms that involve variable "overload" and "underload" game situations, which are achieved using a "floater" or "neutral" player. In our case the presence of the "neutral" player decreased the HR values of participated players.

Hill-Haas et al. (2010) studied the response of athletes to this and they concluded that despite fixed underload teams recording higher RPE compared with the fixed overload teams, there were no differences in physiological responses. During our forms of SSGs with 
the increased number of neutral players the cardiovascular response of players gradually decreased. Finally, according to the authors the use of a floaters appears to be more effective in smaller format games. In our conditions the presence of "neutral" player helped to ensure the fluency of the game.

Halouani et al. (2014b) state that the reduction of player numbers may increase the exercise intensity during SSG in team sports, like in soccer. We found out, that the training load intensity was the most demanding during SSG with equal number of players (3 vs. 3).

Moreover, when using an unequal number of players, the intensity of the SSG is significantly higher for the floater than the other players. Therefore, when using unequal player numbers during SSG, coaches should alternate floating players.

All soccer players should be able to solve game situations in offensive and defensive phase of the game and be ready technically and tactically choose the right decision of game situation solving. Hill-Haas et al. (2011) found out that SSGs containing smaller number of players elicit greater HR values. In training situations, SSGs are often implemented that contain teams of unequal numbers. Reasons for creating an imbalance between opposing teams may include technical development and unavailability of players due to injury. Variation in player number involves creating temporary "overload" and "underload" situations between opposing teams, via the use of "floater" player. The aim of this neutral player transitions to the team in possession of the ball is to create temporary "overload" and "underload" situations. This SSG game design is typically used to develop defensive or attacking proficiency or to increase the physical load on the "floating" player.

Lacome et al. (2018) found out that floaters present decreased external load despite almost unchanged HR responses during SSGs. The SSGs performed on smaller playing fields, in which is involved a lower number of players, are ideal for development and improvement of special match condition and game capacity (Peráček et al. 2018a; Peráček et al. 2018b; Mikulič et al. 2018).

In Table 7 is presented the internal response of the players' organism to the match load according to Mendez-Villaneuva et al. (2013) in the U18 age category. The zones of load intensity were divided at the same rate as in our research work. The intensity of the training load was on the same rate than during the competitive match. In our research was the work interval 2 minutes and the rest interval lasted 2 minutes too. 
Table 7

Intensity of U18 players' match load (Mendez-Villaneuva et al. 2013)

\begin{tabular}{|c|c|c|c|c|c|c|c|c|c|c|}
\hline \multirow{2}{*}{$\begin{array}{l}\text { Zones } \\
\text { Match }\end{array}$} & \multicolumn{2}{|l|}{$\begin{array}{l}<60 \% \\
\mathrm{HR}_{\max }\end{array}$} & \multicolumn{2}{|c|}{$61-70 \% \mathrm{HR}_{\max }$} & \multicolumn{2}{|c|}{$71-80 \% \mathrm{HR}_{\max }$} & \multicolumn{2}{|c|}{$81-90 \% \mathrm{HR}_{\max }$} & \multicolumn{2}{|c|}{$91-100 \% \mathrm{HR}_{\max }$} \\
\hline & 1st half & $\begin{array}{l}\text { 2nd } \\
\text { half }\end{array}$ & 1st half & $\begin{array}{l}2 \text { nd } \\
\text { half }\end{array}$ & 1st half & $\begin{array}{l}\text { 2nd } \\
\text { half }\end{array}$ & $\begin{array}{c}\text { 1st } \\
\text { half }\end{array}$ & 2nd half & $\begin{array}{c}1 \text { st } \\
\text { half }\end{array}$ & 2nd half \\
\hline$[\%]$ & $\begin{array}{c}2.8 \\
\pm 5.8\end{array}$ & $\begin{array}{r}1.0 \\
\pm 1.6\end{array}$ & $\begin{array}{c}6.6 \\
\pm 6.6\end{array}$ & $\begin{array}{c}8.5 \\
\pm 5.7\end{array}$ & $\begin{array}{l}17.3 \\
\pm 9.6\end{array}$ & $\begin{array}{l}26.5 \\
\pm 9.9\end{array}$ & $\begin{array}{c}36.7 \\
\pm 13.3\end{array}$ & $\begin{array}{r}40.8 \\
\pm .8 .1\end{array}$ & $\begin{array}{c}36.5 \\
\pm 22.8\end{array}$ & $\begin{array}{c}22.6 \\
\pm 14.4\end{array}$ \\
\hline
\end{tabular}

During the soccer match the internal response of the organism to the load at different levels. A systematic training process has to stimulate all those bio-energy systems, which predominantly require the match. In practice this criterion is applied with the cognition and suitable manipulation of SSG's variables, including the number of players during the SSGs (Peráček 2014). Coelho et al. (2016) found that the players spent a statistically significant more time above the ANT level in the first half of the match than in the second half. By using small forms of the SSG games, it is possible for us to prepare the players for the load at such level. Soccer nowadays is very physically demanding team sport, SSG with different conditions can enhance the soccer players' capacity. Conditioning preparation through different forms of SSGs are ideal way of improving younger and older players preparedness in fun environment. Our result we can compare with the research work from Bujnovský (2019). During this research program positive changes were demonstrated in physical preparedness of young junior players (U17) after finishing the mesocycle. The author found out positive difference in HR values 1.54 beats. $\min ^{-1}$. The author noted, that improving player's physical preparedness during SSGs is more effective and enjoyable for soccer players.

\section{Conclusions}

The suitable use of modern sports devices in training units, such as sport testers, enable the sports experts to find out the internal response of the soccer players' organism to the training load and get objective feedback on the adequacy of the training load. Our aim was to point out to the internal reaction of the soccer players' organism during the SSGs with different number of "extra" players. In our research the HR values in the SSGs were monitored, in which the number of "neutral" players were different. On the basis of acquired data, can be stated that during the SSGs the $\mathrm{HR}_{\text {mean }}$ values were different. The highest $\mathrm{HR}$ values were recorded in the SSG1 (3 vs. 3), without any "floaters". Soccer players in this SSG remained the longest time 
in the load zone of maximal intensity and spent the most time above the ANT. That's why we can claim that the SSG1 was the most intense one. Among these four SSGs variants the lowest $\mathrm{HR}_{\text {mean }}$ values recorded through the SSG4. It means players spent the minimum of time in the load zone of maximal intensity and above the ANT level as well.

The theoretical part of a modern soccer coach is also based on a training process, which is prepared in advance and well-considered according to the physiological principles. In training units the principles of the player's organism adaptation changes to training stimuli have to be observed. It is important to prepare the players not only in terms of physical capabilities,

but to focus on their game preparedness as well. Our recommendation is to integrate into the systematic training process mainly SSGs with equal number of players or with one extra player who can help create goal opportunities in the offensive phase of the game.

\section{References}

1. AKTAS, S., N. ERKMEN, F. GUVEN \& H. TASKIN, 2014. Effects of the different recovery durations on some physiological parameters during $3 \times 3$ small-sided games in soccer. In: International Journal of Sport and Health Science. 8(12), pp. 134-139. ISSN 1348-1509.

2. ASCI, A., 2016. Heart rate responses during small sided games and official match-play in soccer. In: Sports. 4(2), pp. 1-7. ISSN 2075-4663.

3. BABIC, M., 2016. Vnútorné zat’aženie hráčov v rôznych prípravných hrách vo futbale. [Internal load of football players in vary of small-sided games in football]. Bratislava. Comenius University in Bratislava. Bachelor thesis. Faculty of Physical Education and Sports, Department of Sports Games.

4. BABIC, M. \& M. HOLIENKA, 2018. Komparácia vnútorného zat’aženia brankárov vo futbale $\mathrm{v}$ tréningovom procese. [A comparison of the internal load in soccer training process

of goalkeepers]. In: Studia Sportiva. 12(2), pp. 202-211. ISSN 2570-8783.

5. BABIC, M., M. HOLIENKA \& M. MIKULIČ, 2018. Internal load of soccer goalkeepers during the improvement of selected game activities. In: Journal of Physical Education and Sport. 18(3), pp. 1731-1737. ISSN 2247-8051.

6. BENSON, R. \& D. CONNOLY, 2012. Trénink podle srdečni frekvence. Praha: Grada. ISBN 978-80-247-4036-2. 
7. BRANDES, M., L. MÜLLER \& A. HEITMANN, 2017. Physiological responses, timemotion characterictics and game performance in 4 vs. 4 small-sided games in elite youth soccer players: different number of mini-goals vs. stop-ball. In: Science and Medicine in Football. 1(2), pp. 126-131. ISSN 2473-3938.

8. BUJNOVSKÝ, D., 2019. Efekt základního mezocyklu na změny herní kondice s progresivním charakterem zatižení u hráču mládežnického fotbalu. Disseration theses. Praha. Charles University, Faculty of Physical Education and Sport, Human Movement Laboratory.

9. CAMPOS-VÁZQUEZ, M.A., J.A. GONZÁLES-JURADO, J.A. LEÓN-PRADOS, F. TOSCANO-BENDALA \& L. SUAREZ-ARRONES, 2016. Comparación de la carga interna entre partidos amistosos y un juego condicionado en jugadores profesionales de fútbol. [A comparison of internal load between friendly matches and a conditioned game in professional football players]. In: Cultura, Ciencia y Deporte. 11(31), pp. 67-73. ISSN 1696-5043.

10. CLEMENTE, F.M. \& P.T. NIKOLAIDIS, 2016. Profile of 1-month training load in male and female football and futsal players. In: SpringerPlus. 5(1), pp. [1-10]. ISSN 21931801.

11. CLEMENTE, F.M., P.T. NIKOLAIDIS, C.M.I. VAN DER LINDEN \& B. SILVA, 2017. Effects of small-sided soccer games on internal and external load and lower limb power: A pilot study in collegiate players. In: Human Movement. 18(1), pp. 50-57. ISSN 17323991.

12. COELHO, D.B., R.C. DA PAIXAO, E.C. DE OLIVEIRA, L.K. BECKER, J.B. FERREIRA-JÚNIOR, L.G. COELHO, J.C. DIAS \& E. SILAMI-GARCIA, 2016. Excercise intensity during official soccer matches. In: Revista Brasileira de Cineantropometria \& Desempenho Humano. 18(6), pp. 621-628. ISSN 1415-8426.

13. ENISELER, N., C. SAHAN, I. ÖZKAN \& K. DINLER, 2017. High-intensity small-sided games versus repeated sprint training in junior soccer players. In: Journal of Human Kinetics. 60(1), pp. 101-111. ISSN 1899-7562.

14. GIMÉNEZ, J.V., H. LIU, P. LIPINSKA, A. SZWARC, P. ROMPA \& M.A. GÓMEZ, 2018. Physical responses of professional soccer players during 4 vs. 4 small-sided games with mini-goals according to rule changes. In: Biology of Sport. 35(1), pp. 75-81. ISSN 0860-021X.

15. GIOVANNELLI, M., 2016. The internal load analysis in soccer. LAP Lambert Academic Publishing. ISBN 978-3-659-8595-3. 
16. GONZÁLEZ-RODENAS, J., F. CALABUIG \& R. ARANDA, 2015. Effect of the game design, the goal type and the number of players on intensity of play in small-sided soccer games in youth elite players. In: Journal of Human Kinetics. 49(1), pp. 229-235. ISSN 1640-5544.

17. GONZÁLEZ-VÍlLORA, S., F.M. CLEMENTE, F.M.L. MARTINS \& J.C. PASTORVICEDO, 2017. Effects of regular and conditioned small-sided games on young football players' heart rate responses, technical performance, and network structure. In: Human Movement. 18(5), pp. 77-87. ISSN 1732-3991.

18. HALOUANI, J., H. CHTOROU, A. DELlaL, A. CHAOUACHI \& K. CHAMARI, 2014a. Physiological responses according to rules changes during 3 vs. 3 small-sided games in youth soccer players: Stop-ball vs. small-goals rules. In: Journal of Sports Sciences.

32(15),

pp. 1485-1490. ISSN 0264-0414.

19. HALOUANI, J., H. CHTOROU, T. GABBETT, A. CHAOUACHI \& K. CHAMARI, 2014b. Small-sided games in team sports training: A brief review. In: Journal of Strength and Conditioning Research. 28(12), pp. 3594-3618. ISSN 1064-8011.

20. HAlOUANI, J., H. CHTOROU, A. Dellal, A. CHAOUACHI \& K. CHAMARI, 2017. Soccer small-sided games in young players: Rule modification to induce higher physiological responses. In: Biology of Sport. 34(2), pp. 163-168. ISSN 0860-021X.

21. HILL-HAAS, S. V., A. J. COUTTS, B. T. DAWSON \& G. J. ROWSELL, 2010. Timemotion characteristics and physiological responses of small-sided games in elite youth players: The influence of player number and rule changes. In: Journal of Strength and Conditioning Research. 24(8), 2149-2156. ISSN 1064-8011.

22. HILL-HAAS, S. V., B. T. DAWSON, F. M. IMPELLIZZERI \& A. J. COUTTS, 2011. Physiology of small-sided games training in football. In: Sports Medicine. 41(3), 199220. ISSN 0112-1642.

23. HIPP, M., 2007. Futbal: Rozvoj vybraných pohybových schopností, diagnostika a strečing $v$ družstve vrcholového futbalu. Bratislava: Slovenské pedagogické nakladatel'stvo. ISBN 978-80-10-01146-9.

24. HOLIENKA, M., 1998. Tréningové zat’aženie a interval odpočinku, základné kategórie herného tréningu vo futbale. In: Acta Facultatis Educationis Physicae Universitatis Comenianae, 39. Bratislava: Univerzita Komenského, pp. 147-150. ISBN 80-223-1367-X. 
25. HOLIENKA, M., 2004. Fyziologické odozvy organizmu hráča vo futbale na zat’aženie v prípravnej hre s malým počtom hráčov. In: Zbornik vedeckých prác Katedry športových hier FTVŠ UK, č. 1. Bratislava: Peter Mačura - PEEM, pp. 14-19. ISBN 80-88901-97-9.

26. HOLIENKA, M., 2012. Zat'aženie a zat’ažovanie hráčov $\mathrm{v}$ tréningovom procese $\mathrm{v}$ športových hrách a v závislosti od hráčskej funkcie. In: M. HOLIENKA et al. Tréningové a zápasové zataženie hráča v športových hrách. 1. vyd. Bratislava: ICM Agency, pp. 520.

ISBN 978-80-89257-52-2.

27. HOLIENKA, M., 2016. Internal load of soccer players during preparatory games with a medium number of players. In: Journal of Physical Education and Sport. 16(2), pp. 546-550.ISSN 2247-8051.

28. HOLIENKA, M. \& I. CIHOVÁ, 2016. Vnútorné zat’aženie hráčov vo futbale v prípravných hrách so stredným počtom hráčov. In: Monitorovanie a regulovanie adaptačného efektu $v$ rozličných obdobiach prípravy vrcholových športovcov a talentovanej mládeže. Bratislava: ICM Agency, pp. 132-139. ISBN 978-80-89257-74-4.

29. CHRISTOPHER, J., M. BEATO \& A.T. HULTON, 2016. Manipulation of exercise to rest ratio within set duration on physical and technical outcomes during small-sided games in elite youth soccer players. In: Human Movement Science. 48(August), pp. 1-6. ISSN 0167-9457.

30. KAČÁNI, L., 2005. Futbal: Herná príprava (2) teória a prax. 2. vydanie. Bratislava: Slovenský futbalový zväz. ISBN 89-969091-3-4.

31. KATIS, A. \& E. KELLIS, 2009. Effects of small-sided games on physical conditioning and performance in young soccer players. In: Journal of Sports Science and Medicine. 8(3), 374-380. ISSN 1303-2968.

32. KÖKLÜ, Y., O. SERT, U. ALEMDAROGLU \& Y. ARSLAN, 2015. Comparison of the physiological responses and time-motion characteristics of young soccer players in small-sided games: The effect of Goalkeeper. In: Journal of Strength and Conditioning Research. 29(4), pp. 964-971. ISSN 1064-8011.

33. LACOME, M., B.M. SIMPSON, Y. CHOLLEY \& M. BUCHHEIT, 2018. Locomotor and heart rate responses of floaters during small-sided games in elite soccer players: Effect of pitch size and inclusion of goalkeepers. In: International Journal of Sports Physiology and Performance. 13(5), pp. 668-671. ISSN 1555-0265. 
34. LOS ARCOS, A., J.S. VÁZQUEZ, J. MARTÍN, J. LERGA, F. SÁNCHEZ, F. VILLAGRA

\& J.J. ZULUETA, 2015. Effects of small-sided games vs. interval training in aerobic fitness and physical enjoyment in young elite soccer players. In: PLOS ONE. 10(9), pp. [1$10]$.

ISSN 1932-6203.

35. LÓPEZ-FERNANDÉZ, J., J. SÁNCHEZ-SÁNCHEZ, L. GALLARDO \& J. GARCÍAUNANUE, 2017. Metabolic power of female footballers in various small-sided games with different pitch surfaces and sizes. In: Sports. 5(2), pp. [1-9]. ISSN 2075-4663.

36. MALONE, J.J., A. JASPERS, W.F. HELSEN, B. MERKS, W.G.P. FRENCKEN \& M.S. BRINK, 2018. Seasonal training load and wellness monitoring in a professional soccer goalkeeper. In: International Journal of Sports Physiology and Performance. 12(5), pp. 672-675. ISSN 1555-0265.

37. MORAVEC, R., T. KAMPMILLER, M. VANDERKA \& E. LACZO, 2007. Teória a didaktika výkonnostného a vrcholového športu. Bratislava: Fakulta telesnej výchovy a športu Univerzity Komenského. ISBN 978-80-89075-31-7.

38. MENDEZ-VILlANUEVA, A., M. BUCHHEIT, B. SIMPSON \& P.C. BOURDON, 2013. Match play intensity distribution in youth soccer. In: International Journal of Sports Medicine. 34(2), pp. 101-110. ISSN 0172-4622.

39. MIKULIČ, M., P. PERÁC̆EK \& M. BABIC, 2018. Vplyv prípravných hier na herný výkon elitných mládežníckych hráčov vo futbale. In: Zborník vedeckých prác Katedry športových hier FTVŠ UK č. 25. Bratislava: Slovenská vedecká spoločnost' pre telesnú výchovu a šport, pp. 116-133. ISBN 978-80-89075-75-1.

40. NAGY, N. \& M. HOLIENKA, 2018. Intenzita tréningového zat’aženia v rôznych formách prípravných hier vo futbale. [Intensity of the training load in various forms of preparatory games in football]. In: Telesná výchova \& šport. 28(2), pp. 24-29. ISSN 1335-2245.

41. NAGY, N. \& M. BABIC, 2019. Intenzita tréningového zat’aženia futbalistov v prípravných hrách s rôznymi vel'kost’ami hracej plochy. In: Scientia Movens 2019. Praha: Fakulta tělesné výchovy a sportu, pp. 310-325. ISBN 978-80-87647-48-6.

42. NAGY, N., M. HOLIENKA, M. BABIC, J. MICHÁLEK \& E. KUNZMANN, 2019. Intensity of soccer players' training load in small-sided games with various content focus. 
In: Acta Facultatis Educationis Physicae Universitatis Comenianae. 59(1), pp. 44-68. ISSN 2585-8777.

43. NAGY, N., M. HOLIENKA \& M. BABIC, 2020. Intensity of training load in various forms

of small-sided games in soccer. In: Journal of Physical Education and Sport. 20(1), pp. 53-62. ISSN 2247-8051.

44. OBETKO, M., M. BABIC \& P. PERÁČEK, 2019. Changes in disjunctive reaction time of soccer goalkeepers in selected training load zones. In: Journal of Physical Education and Sport. 19(2), pp. 420-426. ISSN 2247-8051.

45. OWEN, A.L., 2016. Football conditioning: a modern scientific approach, periodization, seasonal training, small sided games. Milton Keynes: Lightning Source. ISBN 978-1-910491-10-2.

46. PERÁČEK, P., 2014. Evidencia a kontrola intenzity tréningového zat’aženia futbalistov. [Registration and control of the training load intensity of footballers]. In: Telesná výchova \& šport. 24(2), pp. 2-6. ISSN 1335-2245.

47. PERÁČEK, P., M. BÔŽIK \& M. MIKULIČ, 2018a. Internal load of elite Malaysian young soccer players in small sided games with different parameters. In: Acta Facultatis Educationis Physicae Universitatis Comenianae. 58(1), pp. 32-43. ISSN 0520-7371.

48. PERÁČEK, P., M. BÔŽIK \& M. MIKULIČ, 2018b. Vybrané charakteristiky vnútorného zat’aženia elitných mladých futbalistov $\mathrm{v}$ prípravných hrách $\mathrm{s}$ rôznymi parametrami. [Internal load of youth elite soccer players in various small-sided games]. In: Studia Sportiva. 12(2), pp. 79-86. ISSN 2570-8783.

49. PRAÇA, G.M., F.M. CLEMENTE, A.G. DE ANDRADE, J.C.P. MORALES \& P.J. GRECO, 2017. Network analysis in small-sided and conditioned soccer games: The influence of additional players and playing position. In: Kinesiology. 49(2), pp. 185-193. ISSN 1311-1441.

50. PROIETTI, R., S. DI FRONSO, L.A. PEREIRA, L. BORTOLI, C. ROBAZZA, F.Y. NAKAMURA \& M. BERTOLIO, 2017. Heart rate variability discriminates competitive levels in professional soccer players. In: Journal of Strenght and Conditioning Research. 31(6), pp. 719-725. ISSN 1064-8011.

51. RANDERS, M.B., J.J. NIELSEN, J. BANGSBO \& P. KRUSTRUP, 2014. Physiological response and activity profile in recreational small sided football: No effect of the number of players. In: Scandinavian Journal of Medicine and Science in Sports. 24(Suppl 1), pp. 130-137. ISSN 1600-0838. 
52. ROJAS-VALVERDE， D., M. MORERA-CASTRO, J. MONTOYA-RODRÍGUEZ \& R. GUTIÉRREZ-VARGAS, 2017. Kinematic demands of two small-sided games of Costa Rican college soccer players. In: Pensar en Movimiento: Revista de Ciencias del Ejercicio y la Salud. 15(1), pp. 66-76. ISSN 1659-4436.

53. SANNICANDRO, I., G. COFANO \& A.R. ROSA, 2016. Heart rate response comparison of young soccer players in "cage" small-sided and 8vs8 games. In: Journal of Physical Education and Spor. 16(4), pp. 1122-1127. ISSN 2247-8051.

54. SANNICANDRO, I. \& G. COFANO, 2017a. Small-sided games: Analysis of the internal load and technical skills in young soccer players. In: International Journal of Science and Research. 6(3), pp. 735-739. ISSN 2319-7064.

55. SANNICANDRO, I. \& G. COFANO, 2017b. Small-sided games in young soccer players: Physical and technical variables. In: MOJ Sports Medicine. 1(1), pp. 1-4. ISSN 25749935.

56. SARMENTO, H., F.M. CLEMENTE, L.D. HARPER, I.T. DA COSTA, A.L. OWEN \& A.J. FIGUEIREDO, 2018. Small sided games in socceer - a systematic review. In: International Journal of Performance Analysis in Sport. 18(5), pp. 693-749. ISSN 24748668.

57. SÁNCHEZ-SÁNCHEZ, J., D. HERNÁNDEZ, D. CASAMICHANA, C. MARTÍNEZSALAZAR, R. RAMIREZ-CAMPILLO \& J. SAMPAIO, 2017. Heart rate, technical performance, and session-rpe in elite youth soccer small-sided games played with wildcard players. In: Journal of Strength and Conditioning Research. 31(10), 2678-2685. ISSN 1064-8011.

58. SGRO, F., S. BRACCO, S. PIGNATO \& M. LIPOMA, 2018. Small-sided games and technical skills in soccer training: Systematic review and implications for sport and physical education practitioners. In: Journal of Sports Science. 6(1), pp. 9-19. ISSN 23327839.

59. TORRES-RONDA, L., B. GONÇALVES, R. MARCELINO, C. TORRENTS, E. VICENTE \& J. SAMPAIO, 2015. Heart rate, time-motion, and body impacts when changing the number of teammates and opponents in soccer small-sided games. In: Journal of Strength and Conditioning Research. 29(10), pp. 2723-2730. ISSN 1064-8011.

60. YOUNG, W. \& N. ROGERS, 2014. Effects of small-sided game and change of direction training on reactive agility and change of direction speed. In: Journal of Sports Sciences. 32(4), pp. 307-314. ISSN 0264-0414. 
61. ZAPLETAlOVÁ, L., G. ARGAJ \& I. POPRÓČIOVÁ, 2017. Effects of an integrated game practice approach to teaching basketball on skills development and game performance.

In: BUND, A. a C. SCHEUER. Changes in Childhood and Adolescence: Current Challenges for Physical Education. Berlin: Logos Verlag Berlin, pp. 254-255. ISBN 9783-8325-4538-3. 